\title{
Life Cycle Analysis Of Solar Pv Panels For Their Efiiciency, Cost And Environmental Performance: A Case Study Of Hyderabad
}

\author{
Muhammad Saad Khan, ShahNawaz Soomro, Wahaj Asif, Arsal Mehmood, \\ Suhail Ahmed \\ Department of Electrical Engineering, Mehran University of Engineering \& \\ Technology, Jamshoro \\ saadkhan.59@yahoo.com
}

\author{
Dr. Nayyar Hussain Mirjat, Dr. Zubair Ahmed Memon \\ Faculty of Electrical Engineering, Mehran University of Engineering \& Technology, \\ Jamshoro
}

\begin{abstract}
As the demand of energy increases, renewable technologies are dominating in the recent years. Solar energy is one of the leading technologies in all of the renewable energies, due to its simplicity. In Pakistan, solar PV stand-alone units are mostly used to meet the energy requirements. During production of solar PV panel, it emits out lot of waste heat and it is necessary to calculate these emissions. This study investigates the complete Life Cycle Analysis (LCA) of two different types of solar panels which are locally available in Hyderabad markets. Complete modeling of Monocrystalline and Polycrystalline PV panels has been done by using GaBi software. This study shows the complete waste heat emissions during each stage of PV panel production. Two different types (Monocrystalline and Polycrystalline) of solar panels are designed under the dimensions of $1 \mathrm{~m} 2$. It is calculated that Monocrystalline PV panels are more efficient than Polycrystalline PV panels and they generates more units of electricity under same temperature conditions during its complete life. To enhance the electrical efficiency of solar PV panel, cooling system must be provided across it. The comparative analysis shows that Polycrystalline PV panels requires less amount of electrical energy as compare to Monocrystalline PV panels resulting in the reduction of waste heat emission. At the end of life, this study highlights the significance of recycling of solar panels which consider the reuse of the raw material. In this study, the combination of mechanical, thermal, and chemical process of recycling is considered. Recycling rate of solar PV panel has been assumed to be $90 \%$. Recycling of raw material reduces the waste heat emission during purification process of raw material. Thus, cost is reduced and beneficial for environmental aspects. Result shows that recycling of solar PV panel is more beneficial than landfill for environmental and economic aspects.
\end{abstract}

\section{Keywords}

Electrical Efficiency, Environmental Factors, Gabi, Landfill, Recycling, Renewable Energy, Solar Photovoltaic Panels, Waste Heat

\section{Introduction}

Energy plays a vital role for the establishment of any country. Advance countries mainly focus on their power sector for the improvement in their economy. Those countries mainly depend on the renewable energies to fulfill their energy demand, economies of these countries drastically increase. However, the power generation from conventional sources greatly harmful for environment because it emits out lot of toxic waste heat (Shukla, Sudhakar and Baredar, 2016). For the sake of environment, it is also necessary to fulfill the energy demands from renewable sources. Due to its many advantages, renewable energies are mostly used across all over the world. In all of the renewable energies, solar energy is one of the dominating technologies due to its many advantages like easy design and ease of maintenance. Fuel of solar energy is free of cost, but due to some complexities still they are restricted like during night solar panels are not able to convert solar energy into electrical energy. Solar panels are used off-grid and on-grid as well (Bhol et al., 2015). They are used on large scale to meet the energy demand globally. However, the efficiency of solar panels is 14 to $17 \%$ only. Up-to today highest 
efficiency of solar panels records $22.8 \%$ only (Bielinskas, 2012). Generally, Solar panels are considered as ecological process for the generation of electricity. In this study a detailed life cycle analysis of Si- solar panels (Polycrystalline, Monocrystalline) is discussed. Mainly the life cycle of solar panel depends on the following processes.
I. Raw Materials.
II. Material Processing.
III. Product Manufacturing.
IV. Use of PV panel.
V. End of life scenarios.

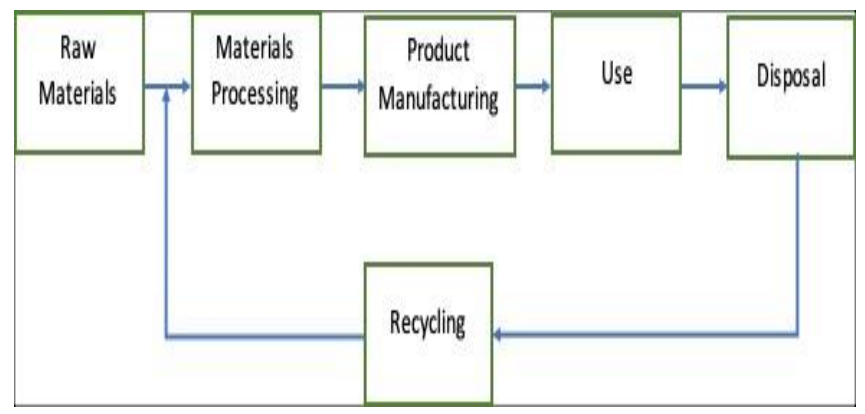

Figure 1: Life cycle of Photovoltaic System

The detailed life cycle of Photovoltaic system is shown in above diagram.

As there are number of studies done in Life Cycle Assessment of PV panel. Almost 1 $\mathrm{kg}$ of Metallurgical Grade silicon produced 46-52 wafers (Hou et al., 2015). Greenhouse gas emissions during complete life cycle is almost $60-87 \mathrm{~g}-\mathrm{CO}_{2}$ per kilo-watt hour (Hou et al., 2015). Efficiency of the solar panel is enhanced when cooling system is provided with panels (Fakouriyan, Saboohi and Fathi, 2019). Efficiency of solar panel can also be decrease by collection of dust on solar PV panel. Thus, output power will also decrease (Bhol et al., 2015). At the end of life recycling is more beneficial than landfill (Sinha et al., 2020).

\section{Methodology}

When The methodology of this study has been divided into three stages.

I. Production of PV panel.

II. Usage of PV panel.

III. End of life scenarios.

In the first stage production of PV panel has been analyzed and this phase is important for the environment because during production of PV panel it emits out lot of waste heat and this heat is very dangerous for the human health. There are several steps has been done during production of PV panel and in this study the waste heat emissions of every step have been calculated.

In the second stage behavior of solar panels in Hyderabad city has been observed and total number of units generated during complete lifetime of solar panel has been calculated and observed which solar panel (Mono and Poly) is generates more electricity during complete life time.

Last stage takes a lot of attention because it is predicted, in 2050 the waste of solar panel will reach up-to 5.5 to 6 million tons per year. Proper handling of waste of solar panel is big issue. PV panels emits out a lot of waste heat if they are not properly disposed at the end of life (Fthenakis, 2000), (Berger et al., 2010).

The methodology of this study has been done by using GaBi software. It is a life cycle assessment software. 


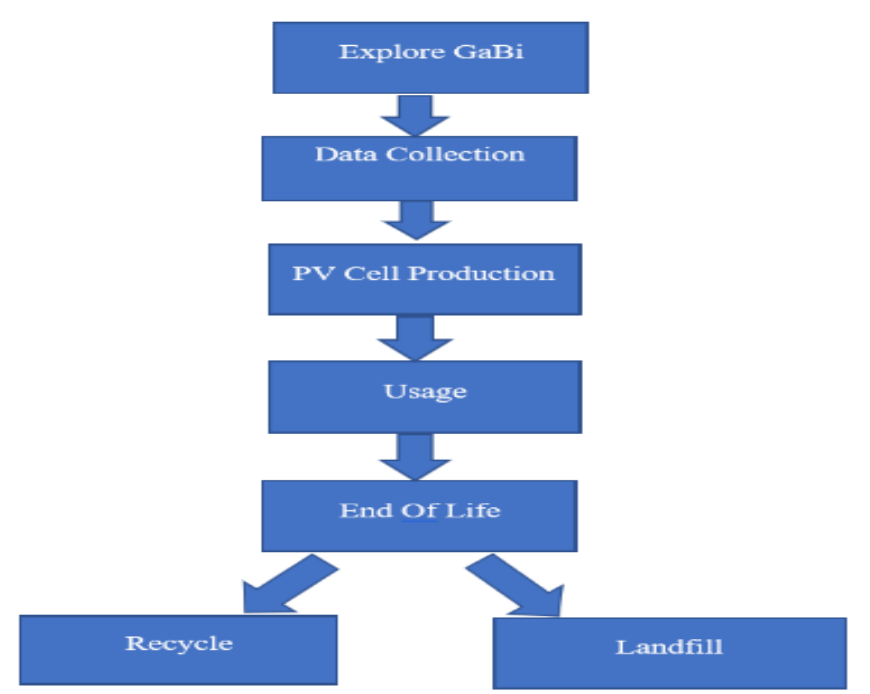

Figure 2. Methodological Framework of this study.

\section{System Design}

Complete life cycle modeling of Mono crystalline and Poly crystalline PV panels can be done by using $\mathrm{GaBi}$ software when two different end of life scenarios are considered.

1) Disposal (Landfill).

2) Recycling

\subsection{Modelling of Monocrystalline PV Panel :}

Figure 3 shows the complete modeling diagram of Monocrystalline PV panel when disposal scenario is considered at the end of life. Number of processes are used during production of solar PV panel. These processes are as follows:

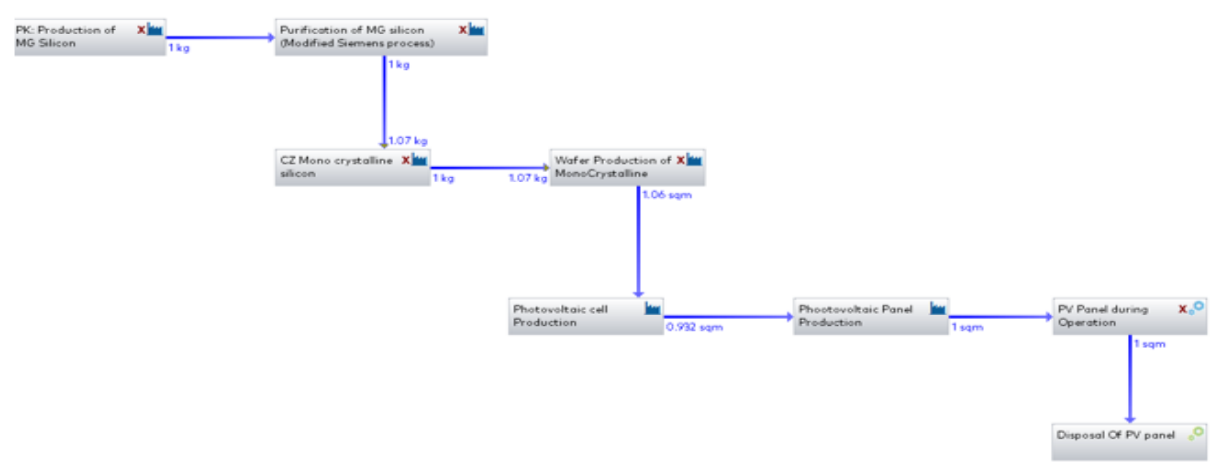

Figure 3: Complete Life Cycle of Monocrystalline PV panel

\subsubsection{Metallurgical Grade Silicon Production :}

In this process oxygen is removed from silica sand by using carbothermic reduction process. In this $1 \mathrm{~kg}$ of Metallurgical grade silicon is produced from $2.7 \mathrm{~kg}$ of silica sand. This process requires bulk quantity of electricity. The complete data of this process is given in Table 1. 
TABLE 1: RAW DATA OF MG-SILICON PRODUCTION.

\begin{tabular}{|l|l|l|l|}
\hline \multicolumn{4}{|c|}{ MG-Silicon Production } \\
\hline Input & Quantity & Output & Quantity \\
\hline Silica sand & $2.7 \mathrm{Kg}$ & MG- Silicon & $1 \mathrm{Kg}$ \\
\hline Charcoal & $0.17 \mathrm{Kg}$ & Waste Heat & $71.3 \mathrm{MJ}$ \\
\hline Electricity & $39.6 \mathrm{MJ}$ & & \\
\hline Hard coal coke (Fuel) & $23.1 \mathrm{MJ}$ & & \\
\hline Oxygen & $0.02 \mathrm{Kg}$ & & \\
\hline Wood Chips & $0.0035 \mathrm{~m}^{3}$ & & \\
\hline Graphite & $0.1 \mathrm{Kg}$ & & \\
\hline
\end{tabular}

3.1.2 Purification of MG-Silicon:

In this process different processes are used to purify the MG-silicon because in photovoltaic applications purified silicon is used. In this study modified-Siemens process is consider for the purification of MG-silicon. The output of this process is solar grade silicon which has impurity level is $0.1 \mathrm{ppm}$. In this study $1 \mathrm{~kg}$ of solar grade silicon is produced from $1 \mathrm{~kg}$ of Metallurgical grade silicon. The complete data of this process is given in table 2 .

TABLE 2: RAW DATA FOR PRODUCTION OF SOLAR GRADE SILICON

\begin{tabular}{|l|l|l|l|}
\hline \multicolumn{4}{|c|}{ MG- Silicon Purification (Modified Siemens Process) } \\
\hline Input & Quantity & Output & Quantity \\
\hline MG-Silicon & $1 \mathrm{Kg}$ & $\begin{array}{l}\text { Silicon solar grade, modified Siemens } \\
\text { process }\end{array}$ & $1 \mathrm{Kg}$ \\
\hline Electricity & $396 \mathrm{MJ}$ & Waste Heat & $396 \mathrm{MJ}$ \\
\hline Hydrochloric acid & $1.6 \mathrm{Kg}$ & & \\
\hline Hydrogen & $0.0501 \mathrm{Kg}$ & & \\
\hline Sodium Hydroxide & $0.348 \mathrm{Kg}$ & & \\
\hline
\end{tabular}

\subsubsection{Production of SC-Silicon:}

In this study Czochralski process is considered, to produce single casted silicon, and in this process hydrogen fluoride and nitric acid is used. This step required large quantity of electricity that is why the cost of single crystalline PV panel is more. In this step $1 \mathrm{~kg}$ of SC- silicon is produce from 1.07 $\mathrm{kg}$ of solar grade silicon. The complete data of this process is given in table 3 .

\section{TABLE 3: RAI DATA OF SINGLE CASTED SLICON PRODUCCION}

\begin{tabular}{|c|l|l|c|}
\hline \multicolumn{4}{|c|}{ SC. Silicon Production } \\
\hline Input & Quantity & Output & Quantity \\
\hline Solar grade silicon & $1.07 \mathrm{Kg}$ & $\begin{array}{c}\text { Single crystalline silicon for } \\
\mathrm{PV} \text { cells }\end{array}$ & $1 \mathrm{Kg}$ \\
\hline Electricity & $308.18 \mathrm{MJ}$ & Waste & $720 \mathrm{MJ}$ \\
\hline Fuel & $68.2 \mathrm{MJ}$ & & \\
\hline Water & $98.48 \mathrm{~m}$ & & \\
\hline Argon & $5.79 \mathrm{Kg}$ & & \\
\hline Hydrogen fluoride & $0.0507 \mathrm{Kg}$ & & \\
\hline Acetic acid & $0.108 \mathrm{Kg}$ & & \\
\hline Ceramic Tiles & $0.336 \mathrm{Kg}$ & & \\
\hline
\end{tabular}




\subsubsection{Production of Wafers:}

In this process silicon ingots are cutting into multiple pieces and these silicon ingots are made up of single and multiple crystal silicon. In this study multi slicing wire machines are used to cut the silicon ingots. In this study 1 unit of wafer is produce from $1.07 \mathrm{Kg}$ of SC-silicon. The complete data of this process is given in table 4 .

TABLE 4 : RAW DATA OF SINGLE CRYSTALLINE SILICON WAFERS PRODUCTION

\begin{tabular}{|l|l|l|l|}
\hline \multicolumn{4}{|c|}{ Single Crystalline Silicon Wafers Production } \\
\hline Input & Quantity & Output & Quantity \\
\hline $\begin{array}{l}\text { Single crystalline silicon for } \\
\text { PV cells. }\end{array}$ & $1.07 \mathrm{Kg}$ & Wafer Production & 1 Unit \\
\hline Electricity & $28.8 \mathrm{MJ}$ & Waste heat & $28.8 \mathrm{MJ}$ \\
\hline Fuel & $4 \mathrm{MJ}$ & & \\
\hline Water & $65 \mathrm{Kg}$ & & \\
\hline Silicon carbide & $0.490 \mathrm{Kg}$ & & \\
\hline Hydrochloric Acid & $0.00270 \mathrm{Kg}$ & & \\
\hline Acetic acid & $0.0390 \mathrm{Kg}$ & & \\
\hline Sodium Hydroxide & $0.0150 \mathrm{Kg}$ & & \\
\hline Tri ethylene Glycol & $0.110 \mathrm{Kg}$ & & \\
\hline
\end{tabular}

\subsubsection{Production of Cells:}

In this step different process like etching, doping, and coating are used to produce solar PV cells. Etching has been done to remove all microscopic damages at wafer surface. Doping has been done to create PN junction. After that, a metallization paste at front and back side of solar panel is made with electrical connection and in the last anti-reflection coating of solar panel is done at the front side of panel to improve the panel's efficiency. In this study 48 cells are used, and the dimension of each cell is $\left(156 \mathrm{~mm}^{*} 156 \mathrm{~mm}\right)$. The complete data of this process is given in table 5 .

TABLE 5 : RaW Data of SiNgle Crystalline SILICON CELL PRODUCTION.

\begin{tabular}{|l|l|l|l|}
\hline \multicolumn{4}{|c|}{ Multi Casted Silicon Cell Production } \\
\hline Input & Quantity & Output & Quantity \\
\hline Single silicon wafer. & $1.06 \mathrm{~m}^{2}$ & PV Cell Production & 1 Unit \\
\hline Electricity & $99.66 \mathrm{MJ}$ & Waste heat & $109 \mathrm{MJ}$ \\
\hline Fuel & $5.93 \mathrm{MJ}$ & & \\
\hline Water & $0.999 \mathrm{~m}^{3}$ & & \\
\hline Metallization Paste at front side & $0.00740 \mathrm{Kg}$ & & \\
\hline Metallization Paste at back side & $0.00493 \mathrm{Kg}$ & & \\
\hline Metallization Paste aluminium at back side & $0.0719 \mathrm{Kg}$ & & \\
\hline Sodium Hydroxide & $0.157 \mathrm{Kg}$ & & \\
\hline Argon & $0.0257 \mathrm{Kg}$ & & \\
\hline Oxygen & $0.102 \mathrm{Kg}$ & & \\
\hline Nitrogen & $1.85 \mathrm{Kg}$ & & \\
\hline
\end{tabular}

\subsubsection{Production of Mono Crystalline PV panel :}

In this study we have considered Hyderabad city and, in this city, the standard size of solar panel which are available locally is between $36-72$ cell in each panel.

In this study 48 cells are combined and made $1 \mathrm{~m}^{2}$ of PV panel. Solar cells relate to electrical connection and panel is made. Different layers are used to protect solar panel from environment. The complete data of this process is given in table 6 . 

PRODUCTION

\begin{tabular}{|l|l|l|l|}
\hline \multicolumn{5}{|c|}{ Monocrystalline Silicon Panel Production } \\
\hline Input & Quantity & Output & Quantity \\
\hline PV cell & $0.932 \mathrm{~m}^{2}$ & PV Panel & 1 Unit \\
\hline Electricity & $\begin{array}{l}16.95 \\
\mathrm{MJ}\end{array}$ & Waste heat & $17 \mathrm{MJ}$ \\
\hline Fuel & $5.41 \mathrm{MJ}$ & & \\
\hline Tap Water & $21.3 \mathrm{Kg}$ & & \\
\hline Tempering, Flat glass & $10.1 \mathrm{Kg}$ & & \\
\hline Copper wire & $0.113 \mathrm{Kg}$ & & \\
\hline Solar glass & $10.1 \mathrm{Kg}$ & & \\
\hline Aluminium alloy & $2.63 \mathrm{Kg}$ & & \\
\hline Sodium Hydroxide & $0.157 \mathrm{Kg}$ & & \\
\hline
\end{tabular}

\subsubsection{Behavior of Monocrystalline Solar Panel in Hyderabad city:}

Generation of electricity from Monocrystalline solar PV panel in Hyderabad city can be calculated from the formula is described below:

$\mathrm{G}=\mathrm{k}^{*} \mathrm{SR} \mathrm{R}^{*} \mathrm{Pr}$

where,

$\mathrm{G}=$ Generation of Monocrystalline PV panel per year.

$\mathrm{k}=$ Monocrystalline PV panel efficiency

$\mathrm{SR}=$ Solar radiation.

$\mathrm{Pr}=$ Performance ratio.

In this study efficiency of Monocrystalline PV panel is considered as $17 \%$. In Hyderabad city the value of solar radiation is $1618 \mathrm{kWh} / \mathrm{m} 2 /$ year [10]. Performance ratio is considered as $78 \%$ because it is location independent.

$G=0.17 * 1618 * 0.78$

$G=214.54 \mathrm{kWh}$ per year.

In this study 25 years of life span of Mono crystalline PV panel has been considered.

$G=214.54$ * 25

$\mathrm{G}=5363.67 \mathrm{kWh}$

\subsubsection{Solar Panel Disposal:}

In this stage it has been assumed that Monocrystalline solar panel has been completely landfilled properly.

\subsubsection{Recycling of Mono Crystalline Solar PV Panel :}

Recycling of Mono crystalline solar PV panel has been described in figure 4. Recycling of Monocrystalline PV panel starts by dismantling the aluminum frame mechanically, then ethyl-vinyl acetate (EVA) is removed thermally, and it has been assumed that glass is recovered safely. In the next step silicon is recovered by using other chemicals. In 2016, an European organization has achieved the recycling rate of solar PV was $96 \%$ by combination of mechanical and thermal process (Kenning, 2016). Recycling rate of solar PV panel has been assumed in this work is $90 \%$. As figure 5 shows that if $90 \%$ of solar panel has been recycled then only $10 \%$ of new amount is added into previous material to make a new Monocrystalline PV panel. It shows that recycling is too much beneficial for environment as well as economy. The complete data require for recycling of $1 \mathrm{~m}^{2} \mathrm{PV}$ panel is given in table 7 . 


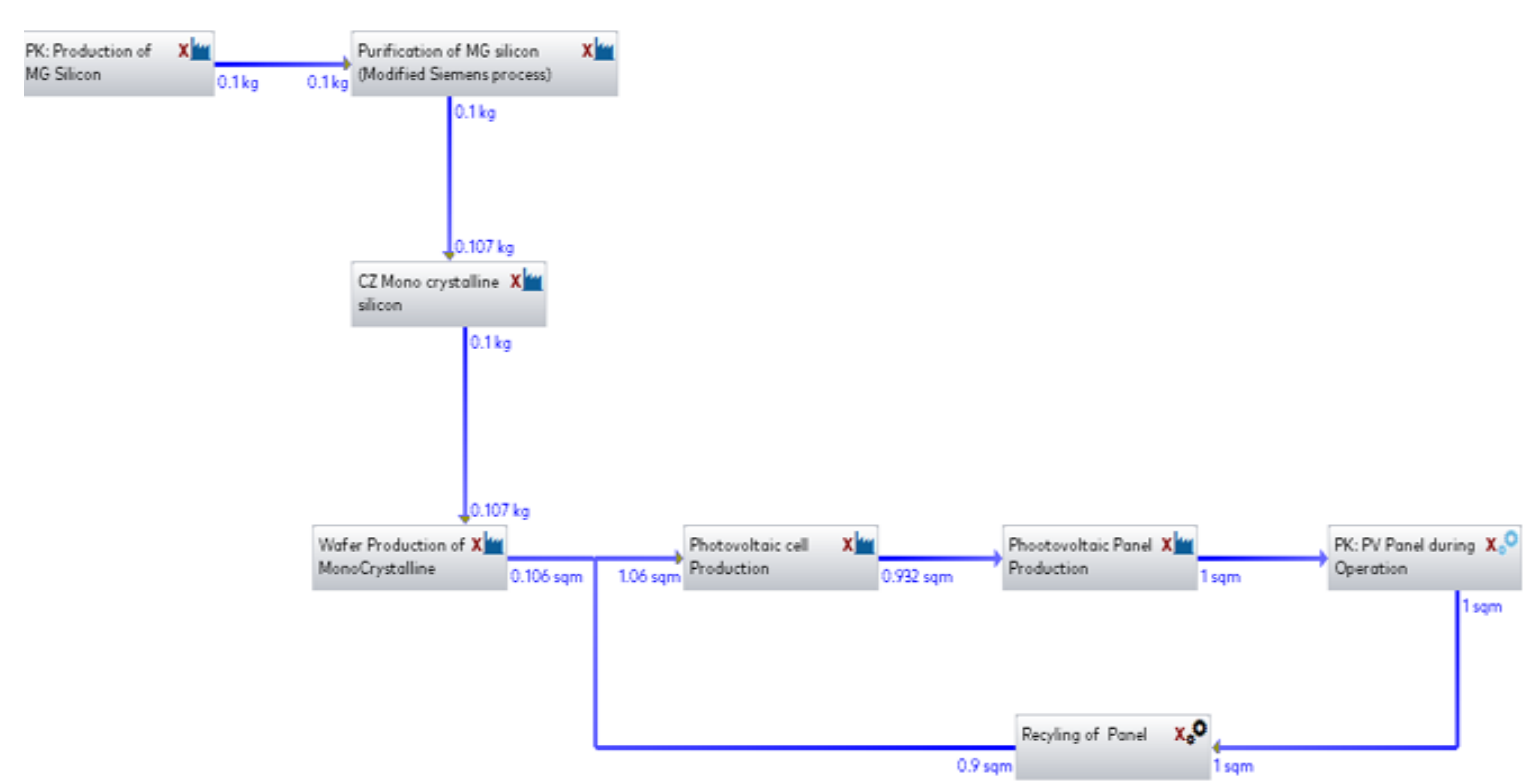

Figure 4: Recycling of Monocrystalline PV Panel and reused again

\subsection{Modelling of Monocrystalline PV Panel :}

Figure 5 shows the complete modelling diagram of Polycrystalline PV panel when disposal scenario is considered at the end of life.

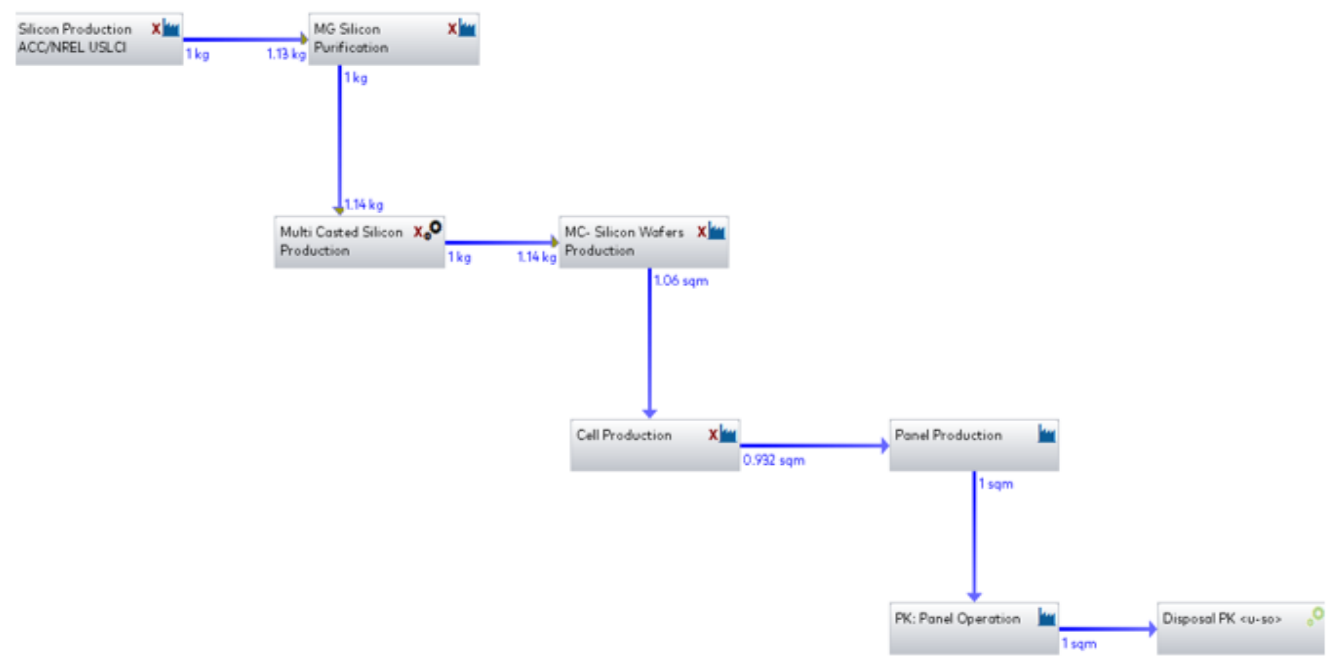

Figure 5: Complete Life Cycle of Polycrystalline PV panel

As in Monocrystalline there are number of processes are done in Polycrystalline. Almost all of the processes are same only difference in the production of Multi-crystalline silicon. These processes are as follows:

3.2.1 Metallurgical Grade Silicon Production:

Same process and data as we discussed in the Monocrystalline PV panel.

\subsubsection{Purification of MG-Silicon:}

Same process and data as we discussed in the Monocrystalline PV panel. 


\subsubsection{Production of Multi-Casted Silicon:}

This type of silicon is cheaper than single casted silicon because less electricity is used. In this type of silicon grain boundaries are present. This step creates a main difference between.

Monocrystalline and Polycrystalline PV panel. $1 \mathrm{~kg}$ of multi casted silicon is produce from $1.14 \mathrm{~kg}$ of solar grade silicon. The complete data of this process is given in table 8 .

TABLE 8: RAW DATA OF MULTI CASTED SILICON PRODUCTION

\begin{tabular}{|c|c|c|c|}
\hline \multicolumn{4}{|c|}{ MC- Silicon Production } \\
\hline Input & Quantity & Output & Quantity \\
\hline Silicon Production mix for PV panels. & $1.14 \mathrm{Kg}$ & Multi casted silicon. & $1 \mathrm{Kg}$ \\
\hline Electricity & $69.5 \mathrm{MJ}$ & Waste & $69.5 \mathrm{MJ}$ \\
\hline Water & $5 \mathrm{~m}^{3}$ & & \\
\hline Argon & $0.267 \mathrm{Kg}$ & & \\
\hline Helium & $\begin{array}{l}0.000119 \\
\mathrm{Kg}\end{array}$ & & \\
\hline Nitrogen & $0.0467 \mathrm{Kg}$ & & \\
\hline Ceramic Tiles & $0.342 \mathrm{Kg}$ & & \\
\hline
\end{tabular}

\subsubsection{Production of Wafers:}

This process is same as we discussed in Monocrystalline PV panel, but here 1 unit of wafer is produced from $1.14 \mathrm{~kg}$ of multi-casted silicon. The complete data of this process is given in the table 9 .

\section{TABLE 9: RAW DATA OF MULTI CASTED SILICON WAFERS PRODUCTION}

\begin{tabular}{|l|l|l|l|}
\hline \multicolumn{4}{|c|}{ Multi Silicon Crystalline Wafers Production } \\
\hline Input & Quantity & Output & Quantity \\
\hline Multi casted silicon. & $1.14 \mathrm{Kg}$ & Wafer Production & 1 Unit \\
\hline Electricity & $28.8 \mathrm{MJ}$ & Waste heat & $28.8 \mathrm{MJ}$ \\
\hline Fuel & $4 \mathrm{MJ}$ & & \\
\hline Water & $65 \mathrm{Kg}$ & & \\
\hline Silicon carbide & $0.490 \mathrm{Kg}$ & & \\
\hline Hydrochloric Acid & $0.00270 \mathrm{Kg}$ & & \\
\hline Acetic acid & $0.0390 \mathrm{Kg}$ & & \\
\hline Sodium Hydroxide & $0.0150 \mathrm{Kg}$ & & \\
\hline Tri ethylene Glycol & $0.110 \mathrm{Kg}$ & & \\
\hline
\end{tabular}

\subsubsection{Production of Cells:}

This process is almost same as we discussed in Monocrystalline PV panel, the only difference is in this type multi silicon wafers are used to produce 48 cells. The complete data of this process is given in table 10 . 
TABLE 10: RAW DATA OF MULTI CASTED SILICON CELL PRODUCTION

\begin{tabular}{|l|l|l|l|}
\hline \multicolumn{4}{|c|}{ Multi Casted Silicon Cell Production } \\
\hline Input & Quantity & Output & Quantity \\
\hline Multi silicon wafer. & $1.06 \mathrm{~m}^{2}$ & PV Cell Production & 1 Unit \\
\hline Electricity & $99.66 \mathrm{MJ}$ & Waste heat & $109 \mathrm{MJ}$ \\
\hline Fuel & $5.93 \mathrm{MJ}$ & & \\
\hline Water & $0.999 \mathrm{~m}^{3}$ & & \\
\hline Metallization Paste at front side & $0.00740 \mathrm{Kg}$ & & \\
\hline Metallization Paste at back side & $0.00493 \mathrm{Kg}$ & & \\
\hline $\begin{array}{l}\text { Metallization Paste aluminium } \\
\text { at back side }\end{array}$ & $0.0719 \mathrm{Kg}$ & & \\
\hline Sodium Hydroxide & $0.157 \mathrm{Kg}$ & & \\
\hline Argon & $0.0257 \mathrm{Kg}$ & & \\
\hline Oxygen & $0.102 \mathrm{Kg}$ & & \\
\hline Nitrogen & $1.85 \mathrm{Kg}$ & & \\
\hline
\end{tabular}

3.2.6 Production of Polycrystalline PV panel:

The procedure of this step is same as we discussed in Monocrystalline PV panel.

\subsubsection{Behavior of Polycrystalline Solar Panel in Hyderabad city:}

Generation of electricity from Polycrystalline solar PV panel in Hyderabad city can be calculated from the formula is described below:

$$
\boldsymbol{G}=\boldsymbol{k} * \boldsymbol{S R} * \boldsymbol{P r}
$$

$G=$ Generation of Polycrystalline PV panel per year.

$k=$ Monocrystalline PV panel efficiency

$S R=$ Solar radiation.

$\operatorname{Pr}=$ Performance ratio.

In this study efficiency of Monocrystalline PV panel is considered as $15 \%$. In Hyderabad city the value of solar radiation is $1618 \mathrm{kWh} / \mathrm{m}^{2} / \mathrm{year}$ (Handayani and Ariyanti, 2012). Performance ratio is considered as $78 \%$ because it is location independent.

$$
\begin{gathered}
G=0.15 * 1618 * 0.78 \\
G=189.306 \mathrm{kWh} \text { per year....... (4) }
\end{gathered}
$$

In this study 25 years of life span of Mono crystalline PV panel has been considered.

$$
\mathrm{G}=189.306 \text { * } 25
$$

$$
G=4732.65 \mathrm{kWh} \text {. }
$$

\subsubsection{Solar Panel Disposal :} properly.

In this stage it has been assumed that Polycrystalline solar panel has been completely landfilled 


\subsubsection{Recycling of Polycrystalline PV panel:}

The recycling processes and data of Polycrystalline PV panel is same as we discussed in Monocrystalline PV panel. Figure 6 shows the complete modeling diagram of Polycrystalline PV panel when recycling scenario is considered at the end of life. The complete data of this process is given in table 7.

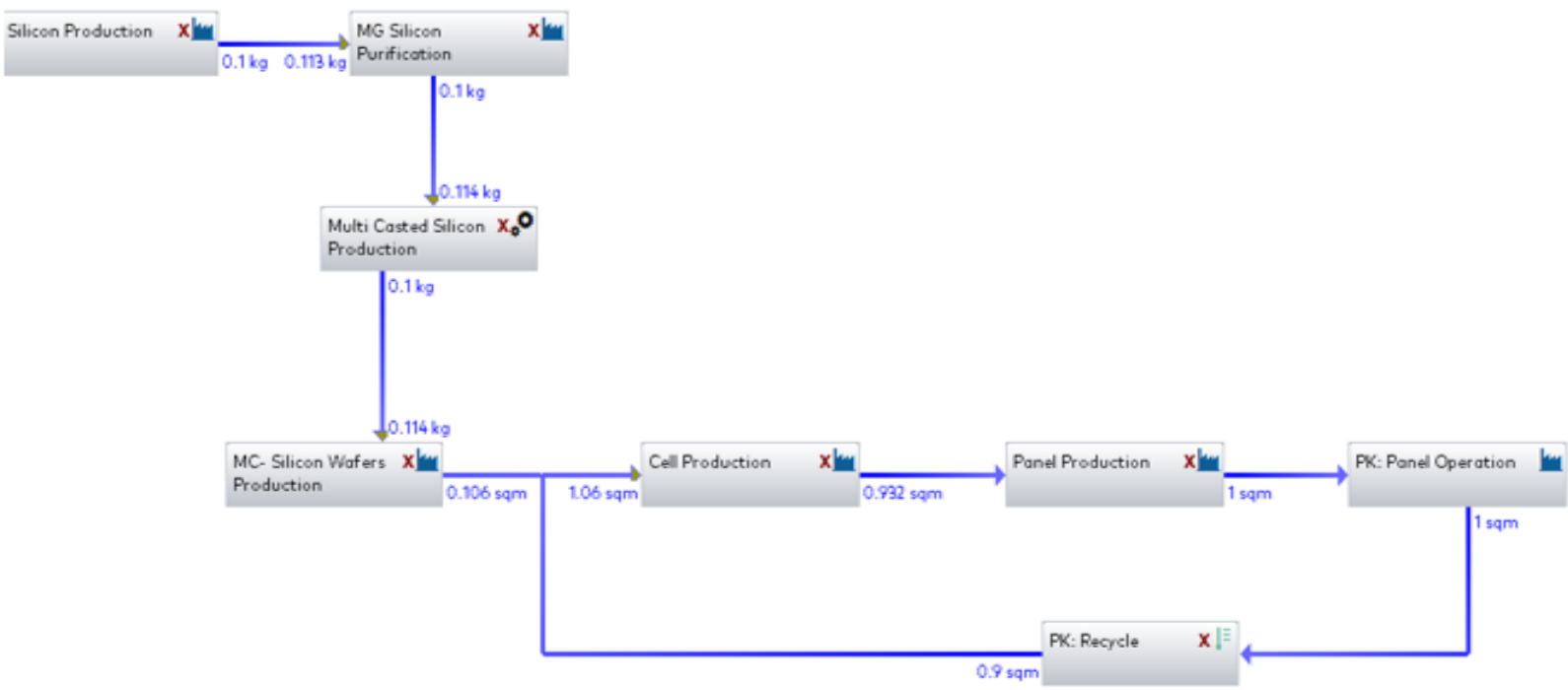

Figure 6: Recycling of Polycrystalline PV Panel and reused again

\section{Results And Discussions}

Complete life cycle analysis of Monocrystalline and Polycrystalline solar PV panel has been discussed in the methodology section. By comparing equation 3 and equation 5 it is understood that $1 \mathrm{~m}^{2}$ of Monocrystalline has generate more amount of electricity than $1 \mathrm{~m}^{2}$ of Polycrystalline PV panel when the irradiance value is same. It shows that Monocrystalline PV panel is preferable as Polycrystalline PV panel because it is much more beneficial.

Figure 7 show the waste heat emission during production of Monocrystalline PV panel when disposal scenario is considered. As result shows production of MG silicon emits out $71.3 \mathrm{MJ}$ waste heat, Purification of MG silicon emits out $396 \mathrm{MJ}$ waste heat, Production of single crystalline silicon emits out $720 \mathrm{MJ}$ of waste heat, Production of wafers emit out 28.8 MJ, Production of cells emits out $109 \mathrm{MJ}$. In the last production of Monocrystalline PV panel emits out $17 \mathrm{MJ}$.

Figure 8 shows the waste heat emission when recycling scenario is considered at the end of life. As result shows if the recycling rate of solar PV panel is $90 \%$, as we considered in this study then production of MG silicon emits out 7.13 MJ waste heat, Purification of MG silicon emits out 39.6 MJ waste heat, Production of single crystalline silicon emits out $72 \mathrm{MJ}$ of waste heat, Production of wafers emit out 2.88 MJ, Production of cells emits out $109 \mathrm{MJ}$. In the last production of Monocrystalline PV panel emits out $17 \mathrm{MJ}$.

Comparative analysis of both scenarios shows that recycling of Monocrystalline PV panel is much more beneficial than disposal because it emits out less amount of waste heat. 


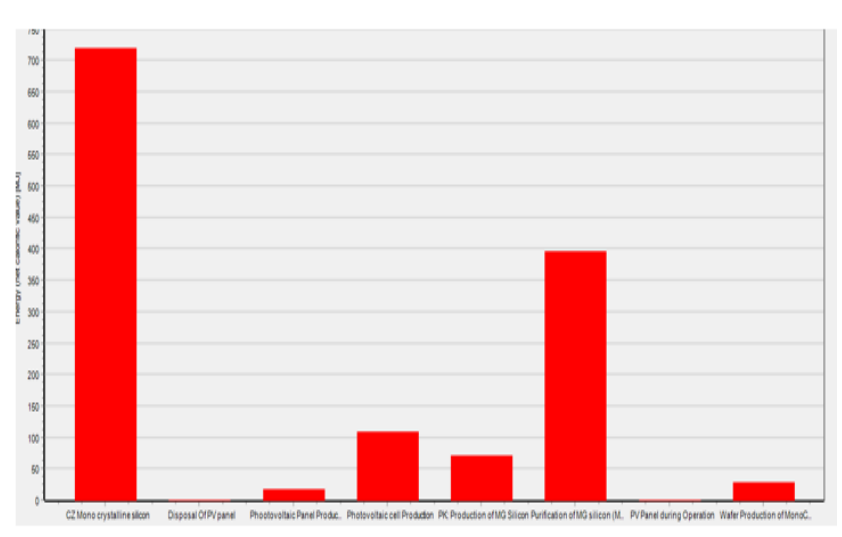

\section{Figure 7: Waste heat emissions during manufacturing of Monocrystalline PV panel.}

Figure 9 show the waste heat emission during production of Polycrystalline PV panel when disposal scenario is considered. As result shows production of $M G$ silicon emits out 71.3 MJ waste heat, Purification of MG silicon emits out 396 MJ waste heat, Production of multi crystalline silicon emits out $69.5 \mathrm{MJ}$ of waste heat, Production of wafers emit out 28.8 MJ, Production of cells emits out 109 MJ. In the last production of Polycrystalline PV panel emits out $17 \mathrm{MJ}$.

Figure 10 shows the waste heat emission when recycling scenario is considered at the end of life. As result shows if the recycling rate of solar PV panel is $90 \%$, as we considered in this study then production of MG silicon emits out 7.13 MJ waste heat, Purification of MG silicon emits out 39.6 MJ waste heat, Production of multi crystalline silicon emits out 6.95 MJ of waste heat, Production of wafers emit out 2.88 MJ, Production of cells emits out $109 \mathrm{MJ}$. In the last production of Polycrystalline PV panel emits out $17 \mathrm{MJ}$.

Comparative analysis of both scenarios shows that recycling of Polycrystalline PV panel is much more beneficial than disposal because it emits out less amount of waste heat.

As result shows, production of single crystalline silicon requires more amount of heat as multicrystalline silicon. That is why single crystalline silicon emits out more waste heat as multi crystalline silicon.

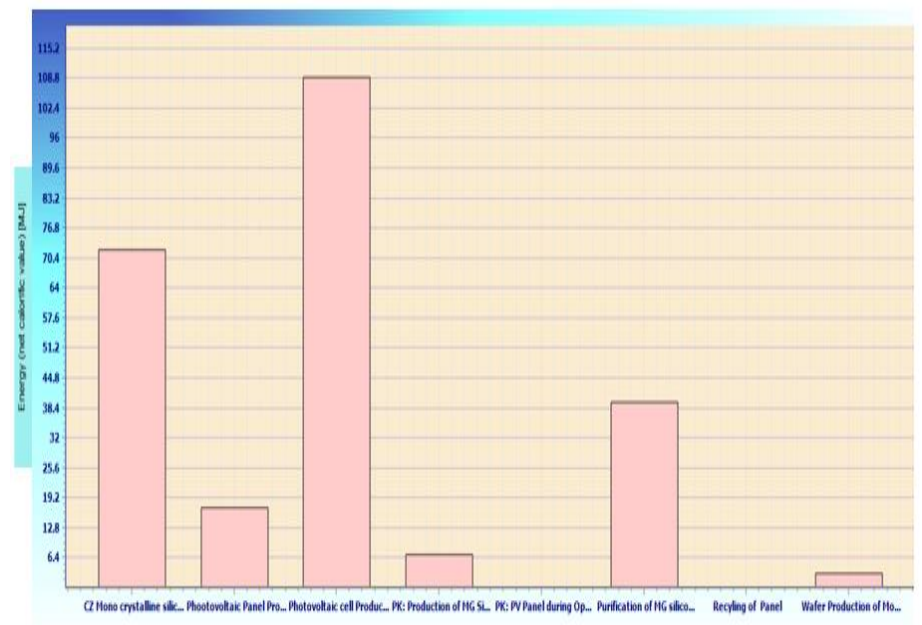

Figure 8: Waste heat emissions during manufacturing of neer PV Monocrystalline panel from recycled panel's

materials. 


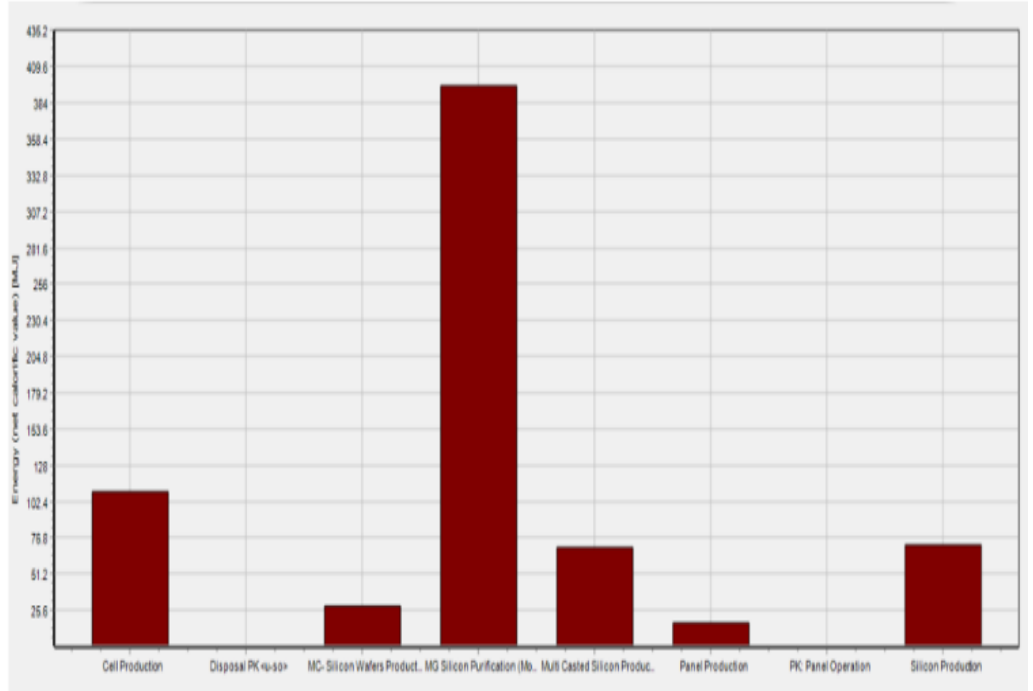

Figure 9: Waste heat emissions during manufacturing of Polycrystalline PV panel.

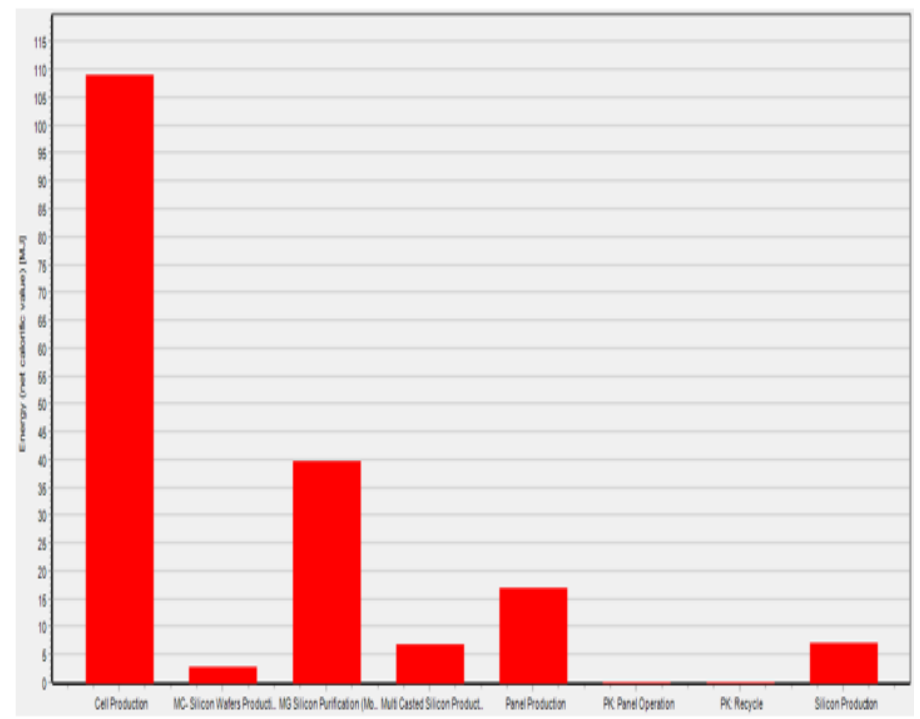

\section{Figure 10: Waste heat emissions during manufiacturing of nere Polycrystalline PV panel from recrcled panel's materials.}

\section{Conclusioon}

The complete life cycle of solar PV panel is considered in this study. This study mainly focuses on two types of solar panels (Monocrystalline and Polycrystalline) which are locally available in Hyderabad Pakistan. This study reveals the characteristics of both panels. In this study life cycle of solar panels is mainly divided into three phases. First stage is production of PV panels. In the first stage we have designed two types of solar panels (Monocrystalline and Polycrystalline). Both panels have same designed. In this study, we have demonstrated the complete data required to produce $1 \mathrm{~m} 2$ solar panel. Second stage is operation of PV panels. We have calculated that the 
output of Monocrystalline PV panel is more than Polycrystalline solar panel at the same irradiance value and same temperature. We have also analyzed that by providing cooling system with solar panels enhances the efficiency of solar PV panels. The last stage of this study gains a lot of attention because the waste of solar panels is increasing rapidly, so proper handling of solar panel waste is big issue. In this study we have further sub-divided the last stage of solar panel into two scenarios, i.e Landfill and Recycling. The results show that recycling of solar panel is more beneficial than landfill for economic and environmental prospects. We have also observed recycling of solar panel reduces the waste heat emissions as well as cost of PV panels.

\section{References}

Berger, W. et al. (2010) 'A novel approach for the recycling of thin film photovoltaic modules', Resources, Conservation and Recycling, 54(10), pp. 711-718. doi: 10.1016/j.resconrec.2009.12.001.

Bhol, R. et al. (2015) 'Environmental effect assessment on performance of solar PV panel', in 2015 International Conference on Circuits, Power and Computing Technologies [ICCPCT2015]. IEEE, pp. 1-5. doi: 10.1109/ICCPCT.2015.7159521.

Bielinskas, V. (2012) Efficiency of Solar energy harvesting, Contruction 21 Internasional. Available at: https://www.construction21.org/articles/h/efficiency-of-solar-energy- harvesting.html (Accessed: 1 February 2021).

Fakouriyan, S., Saboohi, Y. and Fathi, A. (2019) 'Experimental analysis of a cooling system effect on photovoltaic panels' efficiency and its preheating water production', Renewable Energy, 134, pp. 1362-1368. doi: 10.1016/j.renene.2018.09.054.

Fthenakis, V. M. (2000) 'End-of-life management and recycling of PV modules', ELSEVIER, 28, pp. 1051-1058.

Handayani, N. A. and Ariyanti, D. (2012) Potency of Solar Energy Applications in Indonesia Article history, Journal of Renewable Energy Development. Available at: www.jired.com Accessed: 1 February 2021).

Hou, G. et al. (2015) 'Life cycle assessment of grid-connected photovoltaic power generation from crystalline silicon solar modules in China', Applied Energy, 164, pp. 882-890. doi: 10.1016/j.apenergy.2015.11.023.

Kenning, T. (2016) PV Cycle achieves record 96\% recycle rate for silicon-based PV modules, $\quad P V$ Tech. Available at: https://www.pv-tech.org/news/pv-cycle-achieves-record-96- recyclerate-for-silicon-based-pv-modules (Accessed: 1 February 2021).

Shukla, A. K., Sudhakar, K. and Baredar, P. (2016) 'Design, simulation and economic analysis of standalone roof top solar PV system in India', Solar Energy, 136, pp. 437-449. doi: 10.1016/j.solener.2016.07.009.

Sinha, P. et al. (2020) Human Health Risk Assessment Methods for PV Part 3: Module Disposal Risks, International Energy Agency. Sydney. doi: 